\title{
SASTRA SUFISTIK MELAYU DAN SUNDA DI NUSANTARA: MEMPERTEMUKAN HAMZAH FANSURI DAN HAJI HASAN MUSTAPA
}

\author{
Jajang A. Rohmana \\ UIN Sunan Gunung Djati Bandung \\ Jl. A. H. Nasution No. 105, Telp. +62-227800525 Bandung \\ E-mail: jajang_abata@yahoo.co.id \\ HP. +62-81320129296
}

Abstrak: This article is aimed at analyzing the use of local symbols in Sufism literature in Nusantara. The objects of this study are Hamzah Fansuri's poems and Haji Hasan Mustapa's Sufism poems. Both writers were not only the biggest poets but also controversial in two different regions, Malay and Sunda. The analysis used in this study was semantic and intertextual approaches. This study found that there are five similarities between these two writers. First, both writers used poems as a spiritual expression of philosophical Sufism. Second, one of them used local symbolic image of Melayu coastal environment and the other used Pasundan mountainous nature. Third, both of them used poems as biographical expressions. Fourth, they both used quotations of verses or hadits in their poems. The fifth, they both criticized the breakage of Islamic law (syariah). This study shows that Hamzah and Mustapa tended to be philosophical Sufism without ignoring syariah. For that reason, both the criticism of al-Raniri towards Hamzah and one of Sayyid 'Utsmān towards Mustapa are not really appropriate. The differentiation between the creator and the creature in local symbols of Malay and Sunda clearly shows the continuous influence of neo-Sufism on Muslim intellectuals networking along Indonesian Archipelago since $6^{\text {th }}$ century. This study is significant to show that indigenization of Sufism in Indonesian archipelago can be seen in the use of various Sufism symbols, which reflect the background of its nature and culture. This also shows that distinction of Nusantara Islam mysticism identity cannot be separated from great narration of Sufism tradition in the world. In addition, this study strengthens the importance of interconnection between Islam of different culture in two different regions, Malay and Sunda. 
Abstrak: Artikel ini bertujuan menganalisis penggunaan simbolisme lokal dalam sastra sufistik di Nusantara. Objek studinya adalah puisi syair Hamzah Fansuri dan guguritan sufistik Haji Hasan Mustapa. Keduanya tidak saja merupakan sastrawan terbesar, tetapi juga kontroversial di dua kawasan berbeda, Melayu dan Sunda. Analisis menggunakan pendekatan semantik dan interteks. Kajian menunjukkan lima hal penting yang mempertemukan keduanya. Pertama, penggunaan puisi sebagai eskpresi spiritual mistik filosofis. Kedua, penggunaan citra simbolis lokal alam Melayu pesisiran dan alam pegunungan Pasundan. Ketiga, puisi sebagai ungkapan otobiografis. Keempat, kutipan atau reminisensi (iqtibās) ayat atau hadis dalam puisi. Kelima, kritik keduanya atas penyelewengan syariat. Kajian ini menunjukkan bahwa Hamzah dan Mustapa cenderung pada sufistik filosofis yang tidak mengabaikan syariat. Karenanya, kritik al-Raniri atas Hamzah atau Sayyid 'Utsmān atas Mustapa cenderung tidak tepat. Pembedaan khāliq-makhlūq dalam simbol lokal Melayu dan Sunda menegaskan pengaruh arus neo-sufisme yang berkesinambungan dalam jaringan intelektual Islam Nusantara sejak abad ke-16. Kajian ini signifikan untuk menunjukkan bahwa indigenisasi tasawuf di Nusantara tampak pada penggunaan ragam simbol sufistik sebagai cermin latar alam budayanya. Ia menunjukkan distingsi identitas mistisisme Islam Nusantara yang tidak bisa dilepaskan dari narasi besar tradisi sufistik di dunia Islam. Kajian ini juga memperkuat arti penting keterjalinan antara Islam dengan latar budaya di dua kawasan, Melayu dan Sunda.

Kata Kunci: sufi, puisi, simbol, Melayu, dan Sunda.

\section{A. Pendahuluan}

Islam di Asia Tenggara secara historis tidak bisa dilepaskan dari rentang panjang sejarah transmisi jaringan intelektual Islam Nusantara (Azra, 2004). Ia menandai apa yang disebut sebagai proses kelangsungan dan perubahan (continuity and change) sepanjang sejarah peradaban Islam Nusantara. Tak hanya jaringan personal, tetapi yang seringkali terabaikan adalah artikulasi jejaring lokal melalui khasanah tertulis mereka (Knysh, 1995: 40). Terdapat banyak tokoh, karya intelektual dan dinamika perdebatan keagamaan yang berperan penting dalam membentuk arus perubahan tersebut.

Hamzah Fansuri dan Haji Hasan Mustapa merupakan sebagian dari ulama yang memicu perdebatan penting di dua kawasan berbeda di Nusantara. Hamzah di kawasan Melayu Aceh dan Mustapa di Priangan. Hamzah, beserta pelanjutnya Syamsuddin al-Sumatra'i, dianggap heterodoks sehingga mendapat kritik tajam dari al-Raniri pada abad ke-17 (al-Attas, 1970: 31-65; Azra, 
2004: 53; Fathurahman, 2008: 32). Mustapa yang mendapat julukan ulama māhiwal (eksentrik) mendapat serangan melalui 'surat kaleng' dari Sayyid 'Utsmān, ulama kolonial pada awal abad ke-20 (Rosidi, 1989: 88, 434; Kaptein, 1997: 85-102). Keduanya dituduh menganut ajaran sufistik yang dianggap heterodoks dan menyimpang dari ajaran pokok Islam.

Kajian ini berusaha membandingkan dua tokoh penting di dua kawasan tersebut. Meski dibatasi ruang dan waktu berbeda lebih dari tiga abad, tetapi keduanya dipersatukan dalam banyak segi. Tidak hanya peran keduanya dalam mengembangkan ajaran waḥdat al-wujūd yang memicu perdebatan kontroversial pada zamannya, kedudukannya sebagai sastrawan terbesar pada masing-masing kawasan dan minat besar keduanya pada tasawuf filosofis tidak bisa diabaikan. Hamzah bahkan disebut sebagai sastrawan sufi terbesar Nusantara karena dianggap memiliki kontribusi sangat penting dalam perkembangan sastra dan bahasa di dunia Melayu (Ara dkk., 1995: 487; Hadi, 1995: 14; Hadi, 2001: 15-16). Sementara itu, Mustapa dianggap sebagai sastrawan Sunda terbesar dengan lebih dari 10.000 bait dangding sufistik yang tiada bandingannya hingga saat ini (Jahroni, 1999: 79). Selain itu, bukan kebetulan, baik syair Melayu maupun dangding Sunda, kini keduanya semakin terdesak oleh ragam sastra modern seperti sajak, cerpen dan novel.

Membandingkan Hamzah dan Mustapa sangat signifikan bila melihat posisi Mustapa yang selama tiga tahun pernah menjadi penghulu di Aceh. Ia dianggap cukup berhasil menjembatani kebijakan Belanda atas Aceh sebagaimana tampak dalam karyanya berbahasa Melayu, Kasyf al-Sarā'ir fī Haquiquat Atjeh wa Fidr (Or. 7636) yang berisi fatwa dukungannya atas kebijakan kolonial (Ali, 2004: 91-122). Selain itu, belasan ribu puisi sufistiknya juga ditulis tak lama sesudah kepulangannya dari Aceh. Ia menulisnya dalam waktu relatif singkat (1900-1902) (Rosidi, ed., 2003: 263). Kajian ini penting untuk mendudukkan posisi Mustapa dalam jaringan Islam Nusantara. Atmakusumah secara kurang tepat menyebut pengaruh al-Raniri terhadap pemikirannya (Atmakusumah, 1979). Ini dibantah Rosidi bahwa dibanding al-Raniri yang cenderung menyerang Hamzah, justru Mustapa banyak kemiripan dengan Hamzah Fansuri meskipun ia sendiri hampir tidak menyebut-nyebut nama Hamzah dalam karyanya dibanding Ibn 'Arabì dan al-Ghazālì (Rosidi, 2009: 153).

Tulisan ini berusaha membuktikan asumsi Ajip tersebut dengan menunjukkan titik temu antara Hamzah dan Mustapa dalam konteks arus utama neosufisme yang rekonsiliatif di Nusantara. Pendekatan semantik digunakan terhadap sejumlah puisi keduanya yang relevan melalui kajian interteks. Tulisan ini juga memperkuat tesis Abas tentang ragam simbol gnostik dalam khasanah 
literatur mistik Islam termasuk Mustapa (Abas, 1976: 8-10). Selain itu, sejumlah perbedaan juga penting ditekankan terutama terkait latar bahasa dan budaya keduanya dalam mengekspresikan perasaan sufistiknya. Secara lebih luas, kajian ini penting untuk menunjukkan bahwa Islam di dua kawasan menunjukkan pengaruhnya yang tidak sekadar di permukaan. Melayu jelas lebih dahulu terislamisasi dibanding Sunda. Pandangan Snouck tentang dikotomi Islam dan adatrecht di Aceh dan juga Wessing dalam konteks Priangan menunjukkan asumsi yang kurang tepat (Hurgronje, 1906; Wessing, 1974: 286). Kajian ini memperkuat arti penting keterjalinan antara Islam dengan latar budaya di dua kawasan, Melayu dan Sunda.

\section{B. Sastra Sufistik dan Kontroversi KeagamaAn di Nusan- TARA}

Salah satu aspek penting dalam mistik Islam adalah berlimpahannya kreativitas artistik dan sastra. Ekspresi keindahan ini muncul dari keterbatasan bahasa yang tidak dapat menjelaskan perasaannya dalam mencapai puncak spiritualitas kepada orang lain. Bahasa simbol menjadi pilihan dalam menunjukkan perasaannya pada siapapun yang ingin mencapai pengalaman yang sama. Tragedi mistikus kerap terjadi sepanjang sejarah, di saat mistikus harus mereduksi pengalaman personalnya ke level pemikiran abstrak ketika tingkatan komunikasi dengan orang lain menjadi tidak mungkin. Salah satu sarana komunikasi yang digunakan, di mana pelbagai bentuk non-verbal dalam simbol agama sangat dilarang, adalah puisi (Trimingham, 1977: 138-139).

Puisi mampu mewakili perasaan spiritual mistis saat merasakan kedekatannya dengan Tuhan. Karenanya, tidak salah bila dikatakan bahwa sastrawan merupakan penyebar utama pemikiran sufistik. Puisi mampu memproteksi terhadap vulgarisasi dan pelembagaan pemikiran yang dimengerti secara tepat oleh mereka yang memahaminya untuk menghindari tuduhan sesat (Shah, 1977: x). Puisi dan pemikiran mistis bertemu karena berada dalam masalah yang sama, yakni bagaimana mengungkapkan sesuatu yang tidak mudah diungkapkan (Selim, 1990: 26).

Dalam sejarah puisi mistik Islam, berbagai segi keindahan ungkapan spiritual berkembang sejak abad ketujuh. Rabỉ'ah (w. 801), Dzu al-Nūn alMiṣry, Junayd al-Baghdādi (w. 910), Shibli, Ḥallāj, Ibn 'Arabī (w. 1240), dan Ibn al-Farid menandai masa keemasan bait-bait mistik Arab klasik tersebut (Schimmel, 1982: 11-48). Ibn 'Arabī misalnya, selain menuangkan pengalaman mistiknya dalam bentuk rat usan bagian prosa, ia juga mengungkapkan pencerahan paling menakjubkan yang dialaminya ke dalam puisi terutama melalui 
al-Futūhạàt dan Tarjumān al-Asywāq (Halligan, 2001: 286). Namun, dari sekian banyak puisi mistik, sastrawan Persia dikenal paling banyak melahirkan puisi sufistik. Atțāar dan Rumi di antara mistikus yang banyak mendapat perhatian. Karya Aț̣āar, Tadzkirāt al-Awliyā' dan Mantiq al-Ṭayr menyediakan keberlimpahan puisi dan cerita epik yang sangat berpengaruh terhadap mistikus sesudahnya (Smith, 1932). Sedang Matsnawī Rumi dengan hampir 26.000 bait puisi menjadi karya standar mistik Persia yang tiada bandingannya (Schimmel, 1993). Sayangnya, banyak sarjana melewatkan kreativitas sastra sufistik Nusantara. Schimmel misalnya, berhenti pada sastra sufistik India ketika membahas puisi mistik berbahasa lokal (vernaculars) (Schimmel, 1982: 135169). Di satu kesempatan, ia menyebut mistik Islam di Asia Tenggara sekadar epigon dari tradisi Sufistik Arab (Adlin, 2009: 1). Sebuah cara pandang generalis dengan tanpa dilandasi kajian yang cukup memadai.

Di Nusantara, puisi sufistik berkembang paling tidak sesudah abad ke-17. Hamzah dianggap paling menonjol dalam merintis sastra sufistik di dunia Melayu. Begitu pun Ronggowarsito dianggap sebagai salah satu pujangga besar Jawa yang tidak hanya menulis puisi sekar macapat, tetapi juga prosa (Simuh, 1988: 51). Di tatar Sunda, Haji Hasan Mustapa dianggap sebagai sastrawan Sunda terbesar dengan belasan ribu bait puisi dangding sufistik berbahasa Sunda. Sebagaimana akan dijelaskan di depan, Hamzah dan Mustapa pat ut mendapat perhatian tidak saja karena kedudukan keduanya yang sangat berpengaruh dalam jagad sastra di dua kawasan Nusantara, tetapi juga terkait dengan kontroversi keagamaan terkait puisi-puisi mistiknya.

Puisi mistik mewarnai sejarah perdebatan dan kontestasi otoritas keagamaan di dunia Islam termasuk Nusantara. Sebagian ulama sufi memicu perdebatan sengit terkait pemikiran keagamaan yang dianggap heterodoks disertai kepentingan politis yang melatarinya. Abad ke-17 merupakan puncak perdebatan faham sufistik wahdat al-wujūd di kawasan Melayu. Ia bisa dianggap sebagai sisi gelap Islam bagi penganut tasawuf filosofis di kawasan yang seringkali disebut pinggiran (Fathurahman, 2011: 459).

Bermula dari kedatangan Nuruddin al-Raniri, seorang Indo-Arab asal Randir (Gujarat), yang mendapat kedudukan penting di Aceh pada masa Sultan Iskandar Tsani (1637-1641). Ia kemudian menyerang Syamsuddin dan pendahulunya, Hamzah Fansuri, sebagai penyebar ajaran sesat dan heterodoks. Menurutnya, ajaran wujūdiyah sudah menyimpang dari akidah Islam sehingga penganutnya yang tidak mau bertobat bisa dianggap kafir dan dijatuhi hukuman mati. Banyak karya-karya kedua ulama tersebut dibakar di halaman Masjid Baiturahman. Terdapat dua arus besar sarjana dalam memahami kasus 
tersebut. Satu pihak menganggap Hamzah dan Syamsuddin sebagai heretik dan heterodoks sehingga bisa dipahami bila diserang oleh al-Raniri. Pihak lainnya menganggap bahwa al-Raniri sebetulnya menganut paham yang sama dengan Hamzah dan Syamsuddin, tetapi kepentingan politis mendorong munculnya berbagai tuduhan negatif terhadap kedua pendahulunya tersebut (Azra, 2004: $54,64)$.

Selain itu, perdebatan yang hampir sama marak juga di pulau Jawa pada pertengahan abad ke-18. Kasus-kasus seperti Syeikh Siti Jenar, Sunan Panggung, Ki Bebeluk, Syeikh Amongraga, dan Syeikh Ahmad al-Mutamakkin menunjukkan polemik otoritas keagamaan yang terpusat pada masalah paham Manunggaling Kawula Gusti (Bizawie, 2002: 216). Terjadi gesekan antara kecenderungan mistik Sunni dengan falsafi yang diselimuti kepentingan kekuasaan tentang otoritas kuasa agama. Berkembang pula literatur mistik kraton yang berupaya mengadopsi kehidupan sinkretis agama sebagai hasil dari konsiliasi dan harmonisasi mistisisme Jawa tradisional dan legalistik Islam ortodoks (Soebardi, 1971: 349). Ricklefs menyebutnya sebagai bentuk sintesis mistik. Sebuah sintesis yang didasarkan pada tiga pilar utama: identitas Islam yang kuat bagi orang Jawa, pelaksanaan lima rukun Islam, dan penerimaan terhadap realitas spiritual khas Jawa (Ricklefs, 2013: 36-37).

Di tatar Sunda, perdebatan serupa juga terjadi seperti direkam dalam naskah Cerita Perbantahan Dahulu Kala karya Tuanku Nan Garang tahun 1885. Sayyid 'Utsmān memberikan tuduhan sesat terhadap Syaykh Ismail Minangkabau (1125-1180 H) sebagai penyebar Tarekat Khalidiyah Naqsabandiyah. Teks ini disusun sebagai respons terhadap tulisan Sayid 'Utsmān terkait makin meningkatnya aktivitas tarekat tersebut di Jawa Barat tahun 1885 (Shoheh, 2013: 2, 6). Pada saat itu, pemerintah Hindia Belanda sangat mencemaskannya karena jumlah anggota tarekat semakin meningkat tidak hanya dari kalangan rakyat biasa, tetapi juga dari kaum birokrat dan kaum menak setempat seperti Bupati Cianjur, hoofd panghulu (Penghulu Besar) Cianjur, hoofd panghulu Sukabumi, dan Patih Sukabumi (Moriyama, 2005: 148-149). Kekhawatiran ini bisa dipahami karena terkait perlawanan kaum tarekat di Priangan yang sudah muncul sejak awal abad ke-18 (Iskandar, 2001: 60). K.F. Holle sebagai penasehat Belanda dan R.H. Muhammad Musa (1822-1886) selaku hoofd panghulu Limbangan Garut memandang bahwa pengikut tarekat terutama di Cianjur beraliran fanatik sehingga dianggap membahayakan keamanan dan ketertiban. Dalam menghadapi hal ini, Holle menyarankan, melalui surat yang ia kirim kepada Peltzer (Residen Priangan), agar hoofd panghulu Cianjur dan Sukabumi dipecat saja. Sarannya itu tidak bisa dilepaskan dari tulisan kritis Sayyid 'Uts- 
mān tentang tarekat tersebut yang dianggap menyimpang dari ajaran Islam (Burhanudin, 2012: 181).

Polemik Sayyid 'Utsmān ternyata tidak hanya berhenti di situ. Pada tahun 1902, ia juga diduga mengirim surat kaleng kepada Haji Hasan Mustapa. Mustapa dituduh menyimpang dari ajaran Islam karena cenderung mengabaikan syariat. Sebuah isu yang tidak tepat dilihat dari arus besar pemikiran mistiknya yang cenderung rekonsiliatif. Mustapa kemudian menyusun bantahan keras dalam karyanya Injāz al-Wa'd fỉ It fá' al-Ra'd (Or. 7205) (Rosidi, 1989: 88, 434; Kaptein, 1997: 85-102). Dalam Dangding Sinom Piwulang Si Runcangkundang, Mustapa menceritakan pengalaman tersebut. Ia membantah tuduhan kafir dan zindik dengan menegaskan sikapnya sebagai orang yang beuki ti barang éling terhadap syariat (salat dan puasa) (Mustapa, 1960: 53). Banyak sarjana belum memahami posisi Mustapa ini, sehingga dibanding anekdotnya, puisi mistik filosofis Mustapa cenderung terabaikan karena dianggap sulit dipahami sebagaimana dikeluhkan banyak sastrawan Sunda dan sarjana (Rosidi, 1983: 56-57; Millie, 2014: 110-111).

Sebagaimana Sufi Sunni lainnya, tasawuf Mustapa menekankan pada tasawuf rekonsiliatif yang menekankan misteri ketersembunyian Tuhan yang hanya bisa diketahui melalui ciptaan-Nya. Ini misalnya terjadi juga pada tasawuf Hamzah Fansuri (Steenbrink, 1995: 84). Keduanya menggunakan ragam alegori dan simbol yang tetap membedakan antara dirinya dengan Tuhan meski tidak terpisahkan. Kesulitan dalam memahami ragam citra simbolis itulah yang seringkali memicu kesalahfahaman. Persoalan ini menjadi fokus perhatian berikutnya dalam memahami puisi Hamzah dan Mustapa.

\section{Mempertemukan Hamzah dan Mustapa}

Sudah banyak sarjana mengulas tentang kehidupan Hamzah dan polemik terkait kelahirannya (Braginsky, 1999: 135-175; Guillot and Klaus, 2000: 3-24; Braginsky, 2001: 21-33; Guillot and Kalus, 2001: 34-38). Sudah banyak pula kajian tentang ajaran tasawuf yang dianutnya beserta kontroversinya (al-Attas, 1970; Vakily, 1997: 113-135). Ia dikenal sebagai sastrawan sufi Nusantara terbesar. Tak absah bila membahas Islam klasik Nusantara tanpa menyinggungnya. Hingga saat ini belum ada kesepakatan kapan Hamzah lahir dan meninggal. Namun terdapat bukti bahwa ia hidup pada periode awal selama kekuasaan Sultan 'Alā al-Dīn Ri'āyat Syah (berkuasa 997-1011/1589-1602). Hamzah diduga meninggal sebelum 1016/1607. Ia merupakan orang Melayu berasal dari Fansur, dikenal juga sebagai Barus, sebuah pusat pengajaran Islam di pesisir barat Sumatra (Riddell, 2001: 104). 
Hamzah merupakan ulama besar. Ia dilaporkan melakukan perjalanan ke Timur Tengah mengunjungi pusat pengajaran Islam termasuk Mekah, Madinah, Yerusalem, dan Bagdad, tempat ia bergabung ke dalam tarekat Qadiriyah. Ia juga pergi ke Pahang, Kedah, dan Jawa untuk menyebarkan ajarannya. Ia menguasai bahasa Arab, Persia, dan mungkin juga Urdu. Ia merupakan seorang penulis produktif, tidak saja tentang risalah keagamaan, tetapi juga karya prosa dan puisi yang memuat ajaran sufistik. Karenanya, ia dianggap sebagai salah satu mistikus Melayu paling penting pada masa awal dan pelopor tradisi sastra Melayu yang banyak mempengaruhi gaya dan tema karya sastra Melayu sesudahnya. Sastra tasawuf yang ditulisnya menjadi bagian terpenting dalam tradisi Sastra Kitab di kawasan Melayu yang disesuaikan dengan pemahaman masyarakat setempat (Fang, 1991: 380).

Terdapat trilogi sufistik Hamzah yang terkenal: Asrār al- 'Arifīn, Syarab al'Asyiqīn, al-Muntahī. Versi lain Syarab al-'Asyiqin dikenal dengan Zīnat alMuwaḥhidin. Selain itu, terdapat 32 ikat-ikatan atau untaian syair tasawufnya yang ditemukan. Abdul Hadi menyebut terdapat beberapa ciri puisinya yang menonjol: 1) pemakaian penanda kepengarangan; 2) petikan ayat al-Qur'an, hadis, pepatah dan kata-kata Arab; 3) pencantuman nama diri atau julukan; 4) penggunaan tamsil dan citra simbolik sufistik; 5) paduan seimbang antara diksi, rima dan unsur puitik lainnya; 6) memadukan metafisika, logika dan estetika secara seimbang (Hadi, 2012: 3-5).

Rancang bangun puisi Melayu Hamzah sangat luar biasa indah. Syair berbentuk sajak empat baris (quatrains/rubā'i/rubā'iyat) dipenuhi pemilihan imaji-imaji simbolik yang tepat dan menggugah. Terasa sekali jejak pengaruh sastra sufi Persia dalam puisinya. Pemakaiannya pun konsisten dan perulanganperulangan yang terdapat di dalamnya membawa pada suasana ekstase sebagaimana dalam zikir. Struktur puisi semacam ini misalnya bisa dirasakan dalam Syair Perahu berikut (Hadi dalam Hadi dan Ara, t.th.: 28):

1. Inilah gerangan suatu madah mengarangkan syair terlalu indah membetuli jalan tempat berpindah di sanalah i'tikad diperbetuli sudah

2. Wahai muda kenali dirimu ialah, perahu tamsil tubuhmu tiadalah berapa lama hidupmu ke akhirat jua kekal diammu

3. Hai muda arif budiman hasilkan kemudi dengan pedoman 
alat perahumu jua kerjakan

itulah jalan membetuli insan

Dalam beberapa bait syair Hamzah tersebut kelihatan jejak rubā'i Persia. Baris pertama dan kedua mengemukakan gambaran keadaan, baris ketiga interpolasi yang memberi keseimbangan, kadang merupakan kejutan, dan tak jarang pula sekadar jeda dan baris keempat kesimpulan atau maksud sebenarnya. Sajak empat baris Persia merupakan puisi empat baris larik bisa dengan pola rima a-a/a-a, tetapi kebanyakan menggunakan pola rima a-a/b-a. Ia memiliki pola metrum yang khas sesuai dengan panjang pendeknya larik (De Bruijn, 1997: 7). Dalam sastra Persia, rubā'i/rubā'iyat disebut du-baiti, puisi yang terdiri dari dua misra' (rangkap) dan setiap misra' (distichs) terdiri dari dua baris larik, sehingga seluruhnya berjumlah empat larik (Hadi, 2013: 95-96).

Namun, membahas Hamzah tidak lengkap bila tidak mengulas sedikit tentang Syamsuddin al-Sumatra'i (w. 1040/1630). Seorang ulama pelanjut ajaran Hamzah yang sama-sama diserang oleh al-Raniri karena menganut paham wahdat al-wujūd. Umumnya sarjana menganggap bahwa Syamsuddin merupakan murid Hamzah. Bisa dipastikan keduanya pernah bertemu. Sebagaimana Hamzah, Syamsuddin merupakan penulis dan menguasai beberapa bahasa. Ia menulis dalam bahasa Melayu dan Arab kebanyakan tentang kalam dan tasawuf, salah satunya risalah kecil Syarah Rubā'i Hamzah Fansuri. Namun, tidak seperti Hamzah, ia tidak pernah menulis puisi mistik (Azra, 2004: 52-53). Berangkat dari sini kita bisa mempertemukan Mustapa dengan Hamzah dibanding dengan Syamsuddin.

Mustapa adalah sastrawan Sunda terbesar yang menulis belasan karya prosa dan belasan ribu bait puisi sufistik Sunda. Sosok dan karyanya sudah banyak diperkenalkan dan dipublikasikan terutama oleh Ajip Rosidi (Solomon, 1986: 11-27; Rosidi, 1989; Iskandarwassid, Rosidi, Josep CD., 1987; Mustapa, 2009). Pemikiran tasawufnya pun sudah cukup banyak dikaji, baik dari aspek sastra Sunda maupun tasawuf (Rosidi, 1989; Rusyana dan Raksanagara, 1980; Iskandarwassid, Rosidi, Josep CD, 1987; Ekadjati, 1994; Abas, 1976; Jahroni, 1999; al-Bustomi, 2012).

Mustapa pernah tinggal lama di Mekah bergabung dengan komunitas Jawi dan belajar pada banyak ulama, lalu berkeliling Jawa menemani C. Snouck Hurgronje, hingga diangkat sebagai penghulu besar di Kutaraja Aceh dan Bandung. Kedekatannya dengan Snouck tidak dapat diabaikan karena ia menjadi salah satu tokoh kunci yang memberinya kemudahan untuk masuk ke sisi terdalam Islam dan Muslim di Hindia Belanda (Laffan, 2003: 82-84). Karyanya 
dalam bahasa Melayu tentang tanya-jawab Aceh dan Pidie, Kasyf al-Sarā'ir fí Haqiquat Atjeh wa Fidr (Or. 7636), menunjukkan dukungannya atas kebijakan kolonial pada masanya (Ali, 2004: 91-122). Kedudukan Mustapa sebagai elite penghulu Priangan menjadikannya masuk ke dalam lingkaran kaum ménak dan pada gilirannya lingkaran kolonial (Lubis, 1998: 289).

Secara genealogis, karir kesarjanaan Islam Mustapa tidak bisa dilepaskan dari jaringan Nawawi al-Bantani (1813-1879). Snouck menyebut bahwa Mustapa juga belajar padanya (Laffan, 2011: 149). Seorang ulama arsitek intelektual pesantren yang berhasil mendidik sejumlah ulama pesantren terkemuka, seperti Mahfudz Termas (1868-1919) dan Hasyim Asy'ari (1871-1947) (Mas'ud, 2004: 95-132 dan 197-221). Elemen Banten memiliki tempat khusus terutama dalam konteks jaringan ulama Jawi Nusantara abad ke-19.

Latar kehidupan Mustapa sangat berpengaruh terhadap dangding sufistiknya. Harus diakui, Mustapa memang berasal dari keluarga pesantren sekaligus keluarga yang akrab dengan tradisi budaya Sunda (Kartini et.al, 1985: 13). Ia juga dianggap banyak dipengaruhi tradisi mistisisme Islam Nusantara setidaknya setelah berkarir di Aceh (1892-1895) (Rosidi, 2009: 153). Boleh jadi pula, tradisi sastra suluk Jawa memberinya inspirasi setelah mengikuti perjalanan mendampingi Snouck (1887-1889/1889-1890) (van Ronkel, 1942: 311339; Mustapa, 1976: 49). Mustapa mengaku banyak menyalin berbagai primbon, kitab, pusaka dari Jawa yang kemudian diserahkan kepada Snouck yang membayarnya $f 50$ perbulan (Mustapa, 1913: 194). Meskipun besar kemungkinan ia juga sudah mengetahui tentang tradisi tasawuf seperti tampak pada karya Ibn 'Arabì, al-Jilì, al-Ghazāli, dan al-Burhānfürì selama dua belas tahun karirnya di Mekah (1860-1862, 1869-1873, 1877-1882) (Jahroni, 1999: 24, 41). Mustapa terhubung dengan tradisi tarekat Syattariyah di tatar Sunda. Ia diduga memiliki silsilah tarekat Syattariyah yang terhubung dengan Syeikh

1. Kulu-kulu di lalayu,

Kinanti di tanggal hiji,

Boboran Siam Ramadan,

Tilu puluh kali hiji,

Salapan tilu salapan,

Punjul tilu kali hiji.

2. Hiji puluh kali tilu,

Tiluna pancering hiji,

Lima welas kali dua,

Lima-lima genep kali,

Saha nu bisa milangan,

Tanda teu leungiteun hiji.
Kulu-kulu di layu,

Kinanti di tanggal satu,

Berakhir puasa Ramadan,

Tiga puluh kali satu,

Sembilan tiga sembilan,

Tambah tiga kali satu.

Sepuluh kali tiga,

Tiganya hanya pas satu

Lima belas kali dua

Lima lima enam kali

Siapa bisa menghitung

Tanda tak kehilangan satu 
Abdul Muhyi (Christomy, 2001: 74, 82; Christomy, 2008: 105; Hermansoemantri, 1979: 93-96 dan 823). Tulisannya tentang martabat alam tujuh menguatkan pengaruh Ibn 'Arabī, al-Jillì dan al-Burhānfūrì di tatar Sunda terutama melalui Syeikh Abdul Muhyi (Johns, 1965: 5-7). Ini berbeda dengan Hamzah. Meski dipengaruhi ajaran waḥdat al-wujūd, tetapi tak ada bukti tertulis bahwa Hamzah mengajarkan martabat tujuh (Fathurahman, 2011, 454458). Hubungan Mustapa dengan tarekat Syattariyah juga ditegaskan Abas berdasarkan informasi dari Endih Natapraja, pengagum Mustapa, selama satu bulan risetnya di Bandung (Abas, 1976: 35). Karya prosa dan puisi dangding sufistiknya tidak bisa dilepaskan dari latar karirnya yang memungkinkan bersentuhan dengan teks dan tradisi tarekat Nusantara.

Secara struktur, rancang bangun dangding Mustapa memiliki kekhasan terutama pada diksi yang seringkali tidak terduga, permainan mengolah bunyi kata yang bersuara nyaris sama, dan struktur bait-baitnya yang kerapkali menggunakan sampiran sebagai pembuka layaknya rajah dalam pantun Sunda (Setiawan, 2012: 10). Sebagaimana Hamzah, tak jarang ia menggunakan kutipan dan reminisensi ayat atau hadis yang kerap menghiasi larik dangding-nya (iqtibās). Kita lihat bagaimana Mustapa memainkan angka "tiga puluh," sejumlah hari di bulan Ramadan saat ia menyusun puisinya Kinanti Kulu-kulu (Mustapa, 2009: 17-18):

3. Hiji mani ngitung tuhu, Ati mani milang pasti, Kaula nyaho di sukma, Abdi wani ngitung Gusti, Beunang tatanya ka saha, Pamanggih saksi pribadi.

4. Pribadi keur ngadu napsu, Bijil soteh Kangjeng Nabi, Ka qul huwallahu ahad, Bisi kasisipan budi, Jatnika tara midua, Bibit hiji ti ngajadi.
Satu sampai menghitung kesetiaan Hati sampai menghitung pasti Aku tahu dalam sukma Saya berani menghitung Gusti Dapat bertanya pada siapa Temuan saksi pribadi

Pribadi sedang mengadu napsu Keluar juga Kangjeng Nabi Ke qul huwallāhu ahad Khawatir tersisipi budi Jatnika tiada mendua Bibit satu dari sejak menjadi.

Dangding Mustapa juga sebenarnya bukan sekadar konstruksi verbal tetapi juga konstruksi tembang musikal. Terjadi persenyawaan antara ekspresi spiritual dengan cita rasa seni manakala dangding dialunkan. Biasanya dengan iringan kecapi atau instrumen musik lainnya, citra dan simbolisme lokal yang bersumber dari kekayaan batin orang Sunda begitu mudahnya keluar secara 
spontan. Mustapa kerap menggunakan banyak citra simbolik alam kesundaan dalam dangding-nya. Ia menggambarkan hubungan khālik-makhlūk dalam proses pencarian diri yang dijejakkan dalam bingkai tradisi sufistik (Rohmana, 2012: 317).

Dalam tradisi sastra Sunda, sastra sufistik Sunda berkembang setelah masuknya pengaruh budaya Jawa. Sastra Sunda tradisional berbentuk dangding atau guguritan atau juga cerita berupa wawacan semula merupakan karya sastra tulis Jawa-Mataram yang berkembang sekitar abad ke-17. Dangding bisa dianggap menjadi ciri keterpelajaran orang Sunda dalam menyerap pengaruh budaya Jawa. Dangding merupakan karya sastra tulis yang berisi berbagai hal, termasuk cerita (hikayat, roman) atau uraian agama yang ditulis berbentuk puisi dengan pola 17 jenis pupuh (Danasasmita, 2001: 171-172). Seperti halnya macapat di Jawa, dangding dan wawacan biasa ditembangkan atau disenandungkan (Rosidi, 2010: 30-31, 194).

Kedua mistikus besar Nusantara ini menunjukkan kepeloporannya dalam tradisi masing-masing. Hamzah melalui syair-syairnya dalam tradisi sastra Melayu dan Mustapa melalui dangding-nya dalam sastra Sunda. Tak cukup sampai di sini, pertemuan keduanya juga terdapat dalam pesan puisi sufistik yang disusunnya dengan perbedaan latar alam budaya Melayu dan Sunda.

\section{Antara dua Alam Budaya}

Syair dan dangding sebagai karya sastra Nusantara digunakan sebagai ekspresi pengalaman sufistik tidak bisa dilepaskan dari narasi besar tasawuf Islam. Ia menandai apa yang disebut Braginsky sebagai sistem sastra dalam lingkup kesempurnaan rohani (kamāl) (Braginsky, 1998: 435). Syair Hamzah dan dangding Mustapa benar-benar merupakan puisi bermutu tinggi yang penuh simbol, keindahan bunyi, yang menimbulkan asosiasi berlapis-lapis dan seakanakan mengalir secara alami. Puisinya lebih dari sekadar sastra karena merupakan pertemuan antara ekspresi sufistik dengan puisi sebagai wadah atau cangkang suluk-nya. Di satu sisi merupakan ungkapan mistis, tetapi di sisi lain dituangkan ke dalam bentuk sastra puisi sesuai sifat dan watak puisinya sendiri secara tepat. Terjadi penyatuan antara ekspresi sastra sufistik dengan suasana batin dalam suluk-nya sendiri. Efek puitika syair dan dangding terasa sepenuhnya ketika disenandungkan penuh penghayatan.

Dalam konteks narasi besar sufistik, syair Hamzah dan dangding Mustapa mewakili ekspresi tafsir sufistik yang diungkapkan dengan rasa bahasa dan sastra Nusantara. Sebagaimana gubahan puisi sufistik Arab dari al-Ḥallāj, Ibn 
'Arabì, al-Sa'di, Ibn Farid, atau puisi sufistik Persia ala Ațțār dan Rumi, dan banyak sufi kawasan lainnya (Schimmel, 1971), puisi Hamzah dan Mustapa kiranya mengekspresikan hal yang sama. Demikian pula puisi dalam sastra suluk Jawa menunjukkan pengaruh narasi besar sufistik yang diekspresikan ke dalam bahasa puisi lokal Nusantara (Zoetmulder, 1991; Ardani, 1995; Soebardi, 1975). Bahasa simbolis puitik mampu mewakili perasaan spiritual mistis yang dialami oleh siapapun yang merasakan kedekatannya dengan Tuhan.

Oleh karena itu, syair Hamzah dan dangding Mustapa tidak bisa dinafikan memiliki kontribusi besar dalam perkembangan sastra dan pembentukan identitas Islam Nusantara. Ia dianggap menandai puncak capaian sastra Melayu dan Sunda yang belum ditemukan tandingannya pada karya sastra sesudahnya. Bahkan, signifikansi karyanya diakui memiliki sumbangan penting dalam menegaskan hubungan harmonis Islam dan budaya Melayu-Sunda di Nusantara. Baginya, tidak ada dikotomi di antara keduanya sebagaimana diasumsikan Snouck dalam konteks Aceh dan Wessing dalam konteks Sunda. Sebuah cara pandang sinkretis yang sangat diyakini Geertz ketika memandang pekatnya budaya Jawa (Geertz,1976). Sedikitnya terdapat lima hal yang menunjukkan hubungan dekat Hamzah dengan Mustapa dalam konteks tradisi sastra dan jejaring sufistik Nusantara:

\section{Puisi sebagai Ekspresi Spiritual Mistik}

Tak diragukan lagi, Hamzah dan Mustapa menggunakan puisi sebagai sarana pengungkapan beragam pengalaman spiritual mistik secara individual. Ia melanjutkan tradisi besar tasawuf Arab klasik, Persia, dan India dalam mengapresiasi pengalaman rohani ke dalam bentuk sastra puisi. Hamzah melalui trilogi mistik dan puisi rubā'i--nya menuangkan pengalaman unik itu. Sedang Mustapa melalui belasan ribu bait dangding-nya mengungkapkan puncak spiritualnya dalam alunan tembang Sunda. Ekspresi sufistik dalam puisi Hamzah dan Mustapa misalnya tampak dalam bait syair dan dangding berikut (Mustapa, 1976: 140; Rosidi, 1989: 96-97):

Hamzah dalam syair tersebut menggambarkan bahwa manusia hendaknya mengingat akan ilmu dan cahaya pertama yang didapatnya dahulu. Ilmu yang dimaksud merupakan pengetahuan primordial sebagaimana dinyatakan QS. 7: ${ }^{1}$ Artinya: Mencari-cari pijakan eksistensi//hanya Aku kujumpa//Sepanjang mencari siapa/ /hanya Aku kujumpa//Sepanjang mencari berita//hanya yakin kujumpa. Sepanjang mencari selatan//hanya utara kujumpa//sepanjang mencari timur/hanya barat kujumpa//sepanjang mencari ada//hanya tiada kujumpa (terjemah bait terakhir dipinjam dari Teddy AN Muhtadin) 
172, sedang cahaya (nūr) tidak lepas dari konsep Nūr Muḥammad sebagai gambaran kesejatian manusia. Ia juga memberikan nasehat pentingnya berhatihati terhadap hawa nafsu dan memelihara ibadah syariat berupa puasa dan salat. Semua dilakukan untuk membangkitkan kerinduan akan kesejatian supaya bertemu di kedalaman lautan (eksistensial).

\section{Hamzah Fansuri}

'Ilmunya ilmu yang pertama

Madzhabnya madzhab ternama

Cahayanya cahaya yang lama

Ke dalam surga bersama-sama

Ingat-ingat hai anak dagang

Nafsumu itu lawan berperang

Anggamu jadikan sarang

Citamu satu jangan bercawang

Siang hari hendaknya kau sha'im

Malam hari yogya kau qa'im

Kurangkan makan lagi dan na'im

Nafi dan itsbat jangan kau padam

Tuhan kita yang (em)punya 'alam

Menimbul(kan) Hamzah yang sudah karam

'Isyqi-nya jangan kau padam

Supaya washil dengan laut dalam
Haji Hasan Mustapa

Ngalantung néangan tangtung

Aing deui aing deui

Sapanjang néangan saha

Aing deui aing deui

Sapanjang néangan béja

Yakin deui yakin deui

Sapanjang néangan kidul

kalér deui kalér deui

sapanjang néangan wétan

kulon deui kulon deui

sapanjang néangan aya

euweuh deui euweuh deui

Mustapa sebagaimana Hamzah juga mengalami suasana spiritual yang tidak jauh berbeda. Dalam salah satu puisinya yang paling populer tersebut, Mustapa merasakan pertemuan dirinya dengan Tuhan secara eksistensial sehingga ia cenderung bermain simbol dalam pencapaian puncak martabat rohani. Ia bermain dengan citra simbol tangtung-aing, saha-aing, beja-yakin, kidul-kalér, kulon-wétan, manéh-aing, atau aya-euweuh (eksistensi ke Aku, dari siapa ke Aku, dari selatan ke utara, dari timur ke barat, dan dari ada ke tiada).

Hamzah dan Mustapa membedakan diri dan Tuhan dalam konteks waḥdat al-wujūd, yakni sebagai gambaran pertemuan aspek manusia (nasüt) dan aspek ketuhanan (lahüt) dalam dirinya. Jarak keduanya dianggap tak terbatas. Suluk merupakan sebuah perjalanan dari nasüt ke lahüt. Ia menggambarkan pen-

${ }^{2}$ Artinya: Maka orang yang sudah setia//tidak diharapkan hati//manusia sirna sempurna// tak berbaju dan berkain//tak minum tak makan//ternyata cuma terbalik nafas. 
cariannya dari nasūt ke lahüt, dari ombak ke laut, timur ke barat, dari ada ke tiada. Sebuah pencarian anak dagang yang karam di laut dalam. Proses kembali diri ke tempat beranjaknya semula. Keduanya merasakan sudah sampai (wāṣil) dan hilang (sirna) di tempat itu. Keduanya merasakan dirinya kembali "telanjang" ( 'uryān, tara dibaju disamping) (Mustapa, Or. 7878; Iskandarwassid, Rosidi, Josep CD, 1987: 405).

\section{Citra simbolis alam Melayu dan Sunda}

Bahasa simbol merupakan bagian tak terpisahkan dari ekspresi spiritual mistis secara umum (Abou al-Bakr, 1992: 40). Ini bisa dipahami terkait dengan absurditas ungkapan yang tepat bagi Tuhan yang berbeda dari makhluk serta ketidaketisan pengungkapannya secara langsung. Karenanya, simbol menjadi salah satu media yang sangat penting untuk menjembatani pengalaman batin dalam mengungkap berbagai rahasia dalam menempuh jalan Tuhan.

Sebagaimana citra dan simbolisme dalam syair-syair sufistik Arab, Persia dan India yang mencerminkan alam budayanya, maka puisi sufistik Hamzah Fansuri dan Mustapa sering mengemukakan simbol setempat yang luar biasa pula. Zoetmulder sudah menunjukkan aneka simbolisme luar biasa dalam sastra suluk Jawa (Zoetmulder, 1991: 284-320). Tidak diragukan lagi bahwa salah satu kekuatan konsep sufistik keduanya adalah pengungkapannya tentang hubungan dirinya dengan Tuhan yang berakar pada alam kehidupan budaya lingkungannya, yaitu alam Melayu dan Sunda.

Hamzah misalnya menggunakan citra simbolis tidak saja meminjamnya dari para Sufi Arab dan Persia, tetapi juga memakai simbol lokal alam budaya Melayu. Hamzah melukiskan pengalaman spiritual dalam menempuh jalan kerohanian dengan beragam citra simbol seperti anggur atau arak, burung, ikan,

\section{Hamzah Fansuri}

Wali itulah yang menurut firman, Menyembah Tuhan seperti kata Qur'an, Tandanya wasil lagi dan burhan, Memakai pakaian nentiasa 'uryan.
Haji Hasan Mustapa
Nu matak anu geus tuhu
dipikahoréam ati
manusa sirna sampurna
tara dibaju disamping
tara nginum tara dahar
geuning ngan tibalik dami ${ }^{1}$

\footnotetext{
${ }^{3}$ Artinya: Sesama yang kehabisan budi//simbol di pengharapan//laut sungai yang besar// mencari marjan mutiara//Sundanya, mencari mustika//yang tak ditemukan orang//orang yang kurang pengalaman.
} 
lautan dan ombak, kapal, bukit atau puncak gunung, obor atau suluh dan lainnya. Ia juga menggunakan citra simbolik dari kehidupan alam Melayu seperti kayu, kapur barus, dan perahu dengan perlengkapannya. Hal yang sama dilakukan Mustapa yang banyak meminjam citra simbolis alam budaya Pasundan. Perhatikan citra simbolis ombak dan buih dalam karya Hamzah, Asrār al-'Ârifīn dan simbolis laut walungan (sungai) dalam karya Mustapa, Asmarandana Hariring $\mathrm{Nu}$ Hudang Gering berikut (Mustapa, Or. 7883; Iskandarwassid, Rosidi, Josep CD, 1987: 293):

Hamzah Fansuri

Hamzah Fansuri sungguh pun daif, Hakikatnya hampir pada Zat al-Syarif, Sungguh pun habab (buih) rupanya khatib (kasar), Wasilnya (bersatu) daim dengan Bahr al-Latif (Laut yang Halus)
Haji Hasan Mustapa

Sasama nu sisip budi
siloka di pakarepan
laut walungan nu gedé
ngarah marjan mutiara
Sundana ngarah mustika
nu tara timu ku batur
baturna kurang luangna

Sasama nu sisip budi siloka di pakarepan laut walungan nu gedé Sundana marah mustika Sundana ngarah mustika baturna kurang luangna

Hamzah menguraikan konsepnya tentang proses penciptaan alam semesta yang berlaku terus-menerus. Alam tampil sebagai serangkaian manifestasi Zat Ilahi, dari rohani ke jasmani. Ibarat biji yang merangkum seluruh pohon, Zat Ilahi menampung segenap keseluruhan wujud. Dalam aspek-Nya yang transenden (tanzīh), laut Zat Ilahi yang tiada bertepi itu tidak satu atau tidak esa dengan manifestasi-manifestasinya yang ibarat ombak-ombak di permukaan laut. Dalam aspekNya yang imanen, Zat Ilahi pun tidak terpisah atau tidak tercerai dari manifestasi-manifestasinya, ibarat laut yang tidak dapat dipisahkan dari ombak-ombaknya (Braginsky, 1998: 452-453). Hamzah mencoba menempatkan pengalaman sufistiknya dalam lingkungan alam budaya Melayu sebagai bangsa pelaut.

Di tempat lainnya, baik Hamzah maupun Mustapa menggunakan burung sebagai deskripsi metaforik pencarian spiritual mistiknya. Hamzah menulis syair Burung Pingai, sedang Mustapa menulis Dangding Kinanti Unggal Suluk Nutur Manuk (Tiap suluk mengikuti burung) (Mustapa, 1976: 149). Ini mengingatkan kita pada serangkaian alegori mistis melalui cerita burung dalam puisi Aț̣ār, Manțiq al-Tayr (Smith, 1932: 26-28):

\footnotetext{
${ }^{4}$ Artinya: Suluk itu (ibarat) tingkah burung//Burung membawa semua badan//Mencari kenyamanan tempat tinggal//Berubah dari salah satu//Merasa punya sayap sendiri//Terbang lagi terbang lagi.
} 
Hamzah Fansuri

Thayr al- "uryan unggas sulthani Bangsanya nur al-rahmani

Tasbihnya AllahSubhani

Gila dan mabuk akan rabbani

Unggas itu terlalu pingai

Warnanya sempurna bisai

Rumahnya tiada berbidai

Duduknya da'im di balik tirai
Haji Hasan Mustapa

Suluk mah lakuning manuk Manuk ngaringkid jasmani

Nyiar genah pangancikan

Gingsir ti salah sahiji

Rumasa jangjang sorangan

Hiber deui hiber deui ${ }^{1}$

Burung melambangkan perjalanan mistik sufi yang penuh kesulitan dalam perjalanan yang mengantarkannya pada Tuhan. Sebagaimana burung, perlu waktu untuk sālik agar ia dapat menemukan tempat nyaman dalam batinnya. Seringkali pindah dari satu kondisi ke kondisi lain. Berubah-ubah mengikuti arus angin. Hal itu karena dirinya terlalu merasa punya rasa percaya diri dengan akal yang dimilikinya. Akibatnya, manusia seringkali terbang lagi, mencari lagi dan terus mencari lagi. Ini menggambarkan kelemahan manusia dalam mencari hakikat diri yang mengantarkannya pada Tuhan.

Citra-citra yang digunakan Hamzah dan Mustapa umumnya sederhana, mudah dipahami, plastis dan ekspresif. Keduanya menggunakan ragam alegori dan simbol yang tetap membedakan antara dirinya dengan Tuhan meski tidak terpisahkan. Dalam banyak dangding-nya, Mustapa menggunakan ragam alegori dan simbol yang tetap membedakan antara dirinya dengan Tuhan meski tidak terpisahkan. Bila Hamzah membedakan citra simbolis laut-ombak atau kelapa-tempurung misalnya, maka Mustapa menggunakan pembedaan simbol aren dengan caruluk, iwung dan bambu, bambu-haur, bambu-angklung, duwegan-kitri, beras-padi, sirung-benih, tongtolang dengan nangka, hayam dan endog (ayam dan telur) dan yang lainnya (Rohmana, 2013: 325-375). Pembedaan khālik-makhlūk menjadi ciri dari upaya tafsir ulama Nusantara atas ajaran waḥdat al-wujūd. Umumnya ulama sufi Nusantara cenderung mengajukan upaya rekonsiliasi tasawuf (neo-sufisme). Hamzah berada pada arus rekonsiliasi ini di Nusantara abad ke-16. Arus ini berpengaruh besar pada diri Mustapa yang hidup di awal abad ke-20. Tabel berikut menunjukkan perbandingan ragam citra simbolis dalam karya Hamzah dan Mustapa:

\section{Ungkapan Otobiografi dalam Puisi}

Puisi bukan sekadar karya sastra tanpa konteks. Ia menggambarkan pandangan penyair at as situasi zaman di sekelilingnya. Puisi Hamzah meng- 
gambarkan dengan jelas masyarakat Melayu abad ke-16. Ia juga menunjukkan cara Hamzah menjelaskan sejarah panjang perjalanan spiritualnya. Ia seringkali menyebut nama Fansuri di belakang nama asalnya dalam puisi (takhallus) (Hadi, 2001: 138). Sebuah puisi sufistik yang disisipi cerita otobiografis penulisnya. Sebagaimana Hamzah, puisi Mustapa juga menjelaskan cerita otobiografis yang hampir sama. Namanya kerapkali disebut dalam puisinya sendiri sebagai penanda kepengarangan (Rohmana, 2013: 55). Situasi kolonial akhir abad ke19 tergambar dalam puisi dangding-nya. Cerita latar keluarga, pengalaman didaktis kepesantrenan, perjalanannya ke Mekah hingga responsnya at as kontroversi pemikiran tasawufnya banyak menghiasi puisi dangding-nya.

Hamzah Fansuri

Hamzah ini asalnya Fansuri, Mendapat wujud di tanah Syahr Nawi, Beroleh khilafat ilmu yang 'ali, Daripada Abdulqadir Sayid Jailani.

Hamzah Fansuri di dalam Mekkah, Mencari Tuhan di Baitul Ka'bah, Dari Barus ke Kudus terlalu payah, Akhirnya dijumpa di dalam rumah.
Haji Hasan Mustapa

Diri kami keur di Bandung
ngajait wiwitan kami
minangka mulang tarima
tarimakeuneun ku kami
milang lalakon sorangan
nu pibisaeun ngan kami ${ }^{5}$
Jalma sugriyaning jalma
Jalma sugriya manusa
Tamba kélangan jajatén
Dikarang ku kaula
Haji Hasan Mustapa
Jadi hoofd panghulu Bandung
Bayangan santri kabongan 6

Diri kami keur di Bandung gajait wiwitan kami minangka mulang tarima tarimakeuneun ku kami milang lalakon sorangan nu pibisaeun ngan kami ${ }^{5}$

Jalma sugriyaning jalma Jalma sugriya manusa Tamba kélangan jajatén Dikarang ku kaula Haji Hasan Mustapa Bayangan santri kabongan 6

Berikut kutipan puisi keduanya yang mencerminkan dua jenis otobiografis berbeda dari tradisi sastra Nusantara yang berbeda pula (Mustapa, Or. 7876; Or. 7881; Iskandarwassid, Rosidi, Josep CD, 1987: 211).

\section{Kutipan dan Reminisensi dalam Puisi}

Di samping citra simbolis, Hamzah dan Mustapa menggunakan reminisensi (iqtibās) berupa kutipan kata-kata Arab secara lepas dan mahir terutama yang berasal dari ayat al-Qur'an, Hadis, pepatah dan kata-kata Arab, yang beberapa di antaranya telah lama dijadikan metafor, istilah, dan citraan konseptual

\footnotetext{
${ }^{5}$ Artinya: Diri saya ketika di Bandung//mencari hakikat awal saya//sebagai rasa terima kasih//yang diterima oleh saya//menghitung perjalanan sendiri//yang bisa hanya saya. ${ }^{6}$ Artinya: Manusia setiap manusia//Manusia setiap manusia//Supaya tidak kehilangan asal (jati)//Dikarang oleh aku//Haji Hasan Mustapa//Jadi hoofd penghulu Bandung//Bayangan santri kabongan.
} 
penulis-penulis sufi Arab dan Persia (Teeuw, 1994: 16). Tidak kurang 1200 katakata Arab dijumpai dalam 32 ikat-ikatan syair Hamzah (Hadi, 2001: 219-227). Umumnya terdapat dalam syair dakwah dibanding syair simbolik (Braginsky, 1998: 454). Sementara itu, tidak diketahui berapa banyak kutipan kata-kata

Hamzah Fansuri

Mahbubmu itu tiada berhasil,

Pada ainama tuwallu jangan mau ghafil,

Fa samma Wajhullah sempurna wasil, Inilah jalan orang kamil.

Kekasihmu dhahir terlalu terang, Pada kedua alam nyata terbentang, Ahlul makrifah terlalu menang, Wasilnya daim tiada berselang.

Hempaskan akal dan rasamu, Lenyapkan badan dan nyawamu, Pejamkan hendak kedua matamu, Di sana lihat peri rupamu.
Haji Hasan Mustapa

Ari datna mah satuhu dituding samuna muni ditoron lamun ngandika cara babasan kiwari ana ngandika jatnika Wa-ana fí zanni 'abdi 7

$\mathrm{Nu}$ kasebut wamālahum fil ākhirati min khalik taya bagjaning ahérat da bongan tadi teu yakin basa miéling mirasa buriteun kaburu meuting ${ }^{8}$

Arab dalam puisi Mustapa. Semua kutipan reminisensi tersebut menyatu dalam puisi keduanya bahkan terkadang dalam puisi Mustapa redaksi reminisensi tersebut tunduk pada aturan kaidah pupuh (Hasymi dalam Hadi dan Ara, t.th.: 8-9; Mustapa, Or. 7875a; Or. 7875b; Mustapa, 2009: 31).

Hamzah dalam puisinya mengutip ayat fainamā tuwallū fatsamma wajhullāh (QS. 2: 115). Ia menggunakannya sebagai bagian dari ungkapan nasehat spiritual menuju jalan kesempurnaan. Hamzah memenggalnya untuk dijadikan bagian dari larik puisinya sehingga terasa sakralitasnya. Petikan ayat suci itu bukan sekadar tempelan. Ia berfungsi sebagai metafora pinjaman untuk memperkuat pernyataannya (Hadi, 2001: 219-227). Hal yang sama dilakukan Mustapa dengan mengutip sebuah hadis qudsi dan QS. 2: 200. Akan tetapi, Mustapa cenderung memodifikasi kutipannya. Hadis qudsi tersebut diungkapkan dengan redaksi wa ana fï zanni 'abdi. Sesuai dengan aturan kaidah

\footnotetext{
${ }^{7}$ Artinya: Sedangkan dzat-Nya itu tetap//disangka sembunyi-sembunyi//diikuti bila bicara/ /seperti ungkapan sekarang//ketika (Tuhan) Yang Mulya berfirman://Wa-ana fï zanni 'abdi (Dan Aku ada pada persangkaan hamba-Ku).

${ }^{8}$ Artinya: Yang disebut wamā lahum//fi al-ākhirati min khālik//tiada bahagia di akhirat// sebabnya tadi tak yakin//kala ingat, kala merasa//kesorean sampai bermalam.
} 


\begin{tabular}{|l|l|l|l|}
\hline No & \multicolumn{1}{|c|}{$\begin{array}{c}\text { Citra } \\
\text { Simbolis }\end{array}$} & \multicolumn{1}{|c|}{ Hamzah Fansuri } & \multicolumn{1}{|c|}{ Haji Hasan Mustapa } \\
\hline 1. & air & $\begin{array}{l}\text { laut, kabut, awan, hujan, arus, } \\
\text { sungai }\end{array}$ & Walungan(sungai), leuwi, laut \\
\hline 2. & flora & $\begin{array}{l}\text { pohon (biji, batang, cabang } \\
\text { ranting, daun, buah), tanah, } \\
\text { hujan, anggur, kelapa- } \\
\text { tempurung. }\end{array}$ & $\begin{array}{l}\text { Awibambu, kamboja/samboja, } \\
\text { aren-caruluk, iwung-awi, awi- } \\
\text { haur, awi-angklung, duwegan- } \\
\text { kitri, beras-padi, sirung-benih, } \\
\text { tongtolang-nangka, cau (pisang), } \\
\text { jantung pisang }\end{array}$ \\
\hline 3. & fauna & $\begin{array}{l}\text { Burung pinggai } \\
\text { Buruy/kecebong, lancah/laba-laba, } \\
\text { manuk/burung, hayam-endog } \\
\text { (ayam-telur), munding/kerbau }\end{array}$ \\
\hline 4. & lainnya & $\begin{array}{l}\text { perdagangan (kapal dagang, } \\
\text { lunas kapal, papan kapal, isi } \\
\text { atau muatan kapal, laba atau } \\
\text { pendapatan), cahaya, kekasih }\end{array}$ & $\begin{array}{l}\text { Gunung, bukit/pasir, Sangkuriang, } \\
\text { Mundinglaya, waktu, gedong } \\
\text { samar, galudra ngupuk }\end{array}$ \\
\hline
\end{tabular}

pupuh Kinanti yang terdiri dari delapan suku kata berakhiran i (8i). Semula hadis riwayat al-Bukhari dari Abu Hurairah ini menggunakan redaksi ana 'inda zanni 'abdi bi yang cenderung tidak memenuhi aturan suku kata. Mustapa juga mengutip ayat wamā lahum fī al-ākhirati min khalāq (QS. 2: 200) yang diubahnya menjadi min khaliq karena mengejar ujung larik suara vokal (i). Sesuatu yang belum tentu bisa diterima bagi sebagian orang. Dalam bahasa Anderson (1990: 127), ini menjadi contoh representatif bagaimana Sundanisasi al-Qur' an dilakukan sebagai upaya resistensi dan 'penaklukan' orang Sunda terhadap Islam dan bahasa Arab melalui impuls budaya salah satunya sastra Sunda.

Hamzah Fansuri

Segala muda dan sopan,

Segala tuan berhuban,

Uzlatnya berbulan-bulan,

Mencari Tuhan ke dalam hutan.

Segala menjadi sufi,

Segala menjadi shawqi,

Segala menjadi ruhi,

Gusar dan masam di atas bumi.
Haji Hasan Mustapa

Bédja madjarkeun kaula geus leungit elmuning santri geus ngaruksakkeun agama djadi kapir djadi djindik djindikna djadi mungkir kana tutur lampah rasul kana salat puasa ana malik kula njeri kahuruan ngadjawab djeung handaruan. 
Aho segala kita umat Rasuli,

Tunt ut ilmu hakikat al-wusul, Karena ilmu itu pada Allah qabul, I'tiqadmu jangan ittihad dan hulul.

Aho segala kita bernama abid, Sembahyang dan shahadat jangan kau taqlid.

Tunt uti ilmu jangan kepalang di dalam kubur terbaring seorang Munkar wa Nakir ke sana datang menanyakan jikalau ada engkau sembahyang.
Handaruan djeung susumbar
aéh naha kitu teuing
kitu kutan kitu kutan
nu palid tinggaleun palid
palidna nja pribadi
geus ngalun ka alun-alun
alunan nu sampurna
malik ka bagdjaning diri
aduh biang kasampurnaning
sambéang.

Sambéang mustika urang
kabeuki ti barang éling
baheula djadi kalangkang
geusan mihajang miéling
éling2 geus éling
singhoréng tungguling tangtung
tangtung geusan rumingkang
djadi kabeuki aing
aing sirna bagdja teu tjara saria.

di Nusantara. Karenanya, ia menolak sebagian pendapat para sarjana seperti Winstedt, Johns, Van Nieuwenhuijze, dan Baried yang menganggap kasus Hamzah misalnya, sebagai heretik dan heterodoks sehingga bisa dipahami bila diserang oleh al-Raniri (Azra, 2004: 53-54). Sarjana lain seperti Daudy juga menganggapnya menganut panteisme-heterodoks sebagaimana Ibn 'Arabì (Daudy, 2012: 230). Namun, beberapa sarjana lain seperti al-Attas (1970: 31-65), Hadi (t.th.: 18), dan Fathurahman (2011: 459), cenderung membantahnya. Hamzah sebenarnya berada dalam jalur yang sama dengan para penentangnya itu. Keduanya berada dalam arus utama neo-sufisme yang berusaha melakukan rekonsiliasi syariat dengan tasawuf. Arus reformisme tasawuf ini merentang panjang sejak abad ke-17. Hamzah menandai periode

\footnotetext{
${ }^{9}$ Artinya: Isu bahwa Aku//sudah hilang ilmu santri//sudah merusak agama//jadi kafir jadi zindik//zindiknya menjadi mungkir//pada sabda dan amalan rasul//pada salat puasa// sebaliknya Aku merasa sakit hati//bernafsu menjawab penuh semangat; Semangat disertai sesumbar//mengapa kok begitu//ternyat a begini begitu//yang hanyut tinggal hanyut// hanyutnya pribadi//mengambang ke alun-alun//ambangan yang sempurna//kembali ke kebahagiaan diri//aduh biung kesempurnaan sembahyang; Sembahyang perhiasan kita// hobi sejak mulai eling//dulu menjadi bayangan//agar berkeinginan, agar eling//eling-eling sudah eling//ternyata tunggulan eksistensi//eksistensi tempat hidup//menjadi kesukaanku/ /aku sirna bahagia tidak dengan cara yang sama.
} 
awal gerakan tersebut, sedang Mustapa berada di periode awal abad ke-20. Bagian ini berusaha membuktikan bahwa baik Hamzah maupun Mustapa memiliki benang merah yang sama, salah sat unya tampak dalam penegasannya terhadap syariat (shalat, puasa) dan kritiknya terhadap penyimpangan tasawuf (ittihạad, ḥulūI) (Hadi dan Ara, t.th.: 18-21, 28; Mustapa, 1960: 53).

\section{E. Penutup}

Uraian di atas menunjukkan bahwa kesinambungan mistisisme Islam di Nusantara tidak bisa dilepaskan dari arus besar neo-sufistik rekonsiliatif. Hamzah dan Mustapa merepresentasikan arus reformisme tasawuf tersebut meski berasal dari ruang waktu dan budaya berbeda. Keduanya dipersatukan dalam banyak hal, bukan saja jejak pemikirannya yang kerap disalahpahami dan dianggap kontroversial, tetapi kontribusi besarnya terhadap perkembangan sastra di dua kawasan (Melayu dan Sunda) sama sekali tidak diragukan. Pertemuan keduanya sangat tampak dalam ungkapan puisi sufistik (syair dan dangding) yang dijejakkan dalam latar budaya dan simbolisme lokal Nusantara. Kajian ini sangat signifikan dalam rangka memperkuat identitas sastra dan tasawuf Nusantara. Tentu saja bukan hanya di Melayu dan Sunda. Sastra sufistik dengan ragam latar alam budaya juga terdapat di berbagai kawasan Nusantara, seperti Ronggowarsito, Mangku Nagara dan Yasadipura di Jawa, Muhammad Yusuf al-Makasari di Sulawesi, Muhammad Nafis al-Banjari di Kalimantan, Daud al-Fatani di Pilipina, dan lainnya. Inilah wujud distingsi identitas mistisisme Islam Nusantara. Ia memiliki posisi yang sama sebagaimana tradisi sufistik Arab, Persia, India, dan Afrika dalam membentuk narasi besar mistisisme Islam di seluruh dunia.

\section{Daftar Pustaka}

Manuskrip

Mustapa, Haji Hasan. Kasyf al-Sarā'ir fị Haquiquat Atjeh wa Fidr, Cod. Or. 7636.

UB Leiden University. . Injāz al-Wa'd fî Iṭâ' al-Ra'd, Cod. Or. 7205. UB Leiden University. . Kinanti Tutur Teu Kacatur Batur, Cod. Or. 7875a. 16 Agustus 1901.

UB Leiden University. . Kinanti Kulu-kulu di Lalayu, Cod. Or. 7875b. UB Leiden University. . Kinanti Gaduh Panglipuran Galuh, Cod. Or. 7881. UB Leiden University. 

. Asmarandana Hariring $\mathrm{Nu}$ Hudang Gering, Cod. Or. 7883. UB Leiden University.

Buku dan Artikel

Abas, Lutfi. 1976. "Prolegomena to Haji Hasan Mustapa's Mystical Cantos." Paper presented at a seminar in The Department of Malay Studies on October 6.

Abou al-Bakr, Omaima. 1992. "The Symbolic Function of Metaphor in

Medieval Sufi Poetry: The Case of Shushtari”, Alif: Journal of Comparative Poetics. 12: 40-57.

Adlin, Alfathri. 2009. "Haji Hasan Mustapa Antara Tasawuf, Filsafat dan Teologi Simulakra," paper pada acara Sawala Mesek Karya Haji Hasan Mustapa, UIN Bandung.

Ali, Mufti. 2004. “A Study of Hasan Mustafa's Fatwa: It is Incumbent upon the Indonesian Muslims to be Loyal to the Dutch East Indies Government," Journal of the Pakistan Historical Society, April, Vol. 52 Issue 2. Anderson, Benedict R. O'G. 1990. "The Languages of Indonesian Politics," dalam Language and Power: Exploring Political Cultures in Indonesia. Ithaca: Cornell University Press.

Ardani, Moh. 1995. Al-Qur'an dan Sufisme Mangkunegara IV (Studi SeratSerat Piwulang). Yogyakarta: Dana Bhakti Wakaf.

Atmakusumah, Hasan Wahyu. 1979. "Saliwat Ngeunaan Nuruddin Arraniri jeung Haji Hasan Mustapa,” Mangle, No. 704, 18 Oktober.

Al-Attas, Syed Muhammad Naguib. 1970. The Mysticism of Hamzah Fansuri. Kuala Lumpur: University of Malaya Press.

Azra, Azyumardi. 2004. The Origins of Islamic Reformism in Southeast Asia: Networks of Malay-Indonesian and Middle Eastern 'Ulamà' in the seventeenth and eighteenth centuries, Honolulu: ASAA-Allen \& Unwin and University of Hawaii Press.

Bizawie, Zainul Milal. 2002. Perlawanan Kultural Agama Rakyat, Yogyakarta: Sahma-Yayasan Keris.

Braginsky, V. I. 1998. Yang Indah, Berfaedah dan Kamal: Sejarah Sastra Melayu dalam Abad 7-19. trans. Hersri Setiawan. Jakarta: INIS. . 1999. "Towards the Biography of Hamzah Fansuri. When Did Hamzah Live? Data from His Poems and Early European Accounts," Archipel, Vol. 57: 135-175. 
. 2001. "On the Copy of Hamzah Fansuri's Epitaph Published by

C. Guillot \& L. Kalus,” Arcipel, Vol. 62: 21-33.

Burhanudin, Jajat. 2012. Ulama \& Kekuasaan: Pergumulan Elite Muslim dalam

Sejarah Indonesia. Bandung: Mizan.

Al-Bustomi, Ahmad Gibson. 2012. Filsafat Manusia Sunda: Kumpulan Esai

HHM, Teosofi dan Filsafat, Bandung: Skylart Publisher.

Christomy, Tommy. "Shattariyah Tradition in West Java: the Case of Pamijahan," Studia Islamika, Vol. 8, No. 2, 2001.

. 2008. Signs of the Wali: Narratives at the Sacred Sites in Pamijahan,

West Java. Canberra: ANU E Press.

Danasasmita, Ma'mur. 2001. Wacana Bahasa dan Sastra Sunda Lama.

Bandung: STSI Press.

Daudy, Ahmad. 2012. Allah and Human Being in the Conception of Syeikh

Nuruddin Ar-Raniry, Jakarta: Puslitbang Lektur dan Khazanah

Keagamaan Badan Litbang dan Diklat Kementerian Agama RI.

De Bruijn, J.T.P. 1997. An Introduction to the Mystical Use of Classical Poems,

Great Britain: Curzon Press.

Ekadjati, Edi S. 1994. Empat Sastrawan Sunda Lama. Jakarta: Depdikbud.

Fang, Liaw Yock. 1991. Sejarah Kesusasteraan Melayu Klasik. Jakarta: YOI.

Fathurahman, Oman. 2008. Tarekat Syattariyah di Minangkabau. Jakarta:

Prenada Media, EFEO, PPIM, KITLV.

. 2011. "Sejarah Pengkafiran dan Marginalisasi Paham Keagamaan

di Melayu dan Jawa," Analisis, Vol. XI, No. 2, Desember.

Geertz, Clifford. 1976. The Religion of Java. Chicago: University of Chicago Press.

Guillot, Claude and Ludvik Kalus. 2000. "La Stéle Funéraire de Hamzah Fansuri," Archipel, Vol. 60: 3-24.

. 2001. "En résponse a Vladimir I. Braginsky," Archipel, Vol.

62: 34-38.

Hadi WM., Abdul. 1995. Hamzah Fansuri: Risalah Tasawuf dan Puisi-puisinya, Bandung: Mizan.

. TT. "Hamzah Fansuri Bapak Sastra dan Bahasa Melayu,"

dalam Abdul Hadi W.M. dan L.K. Ara (penyunting), Hamzah Fansuri Penyair Sufi Aceh, Lotkala.

. 2001. Tasawuf Yang Tertindas, Kajian Hermeneutik Atas

Karya-Karya Sastra Hamzah Fansuri. Jakarta: Paramadina. 
. 2012. "Jejak Sang Sufi: Hamzah Fansuri dan Syair-syair

Tasawufnya," Makalah Seri Kuliah Umum "Islam dan Mistisisme Nusantara" di Teater Salihara, 21 Juli 2012.

. 2013. "Jejak Persia dalam Sastra Melayu," Media Syariah,

Vol. XV, No. 1, Januari-Juni.

Halligan, Fredrica R. 2001. "The Creative Imagination of the Sufi Mystic, Ibn 'Arabī, Journal of Religion and Health, Vol. 40, No. 2. Summer.

Hasjmy, A. 1995. "Hamzah Fansuri Sastrawan Sufi Terbesar Nusantara," dalam

L.K. Ara, Taufiq Ismail dan Hasyim KS., ed., Seulawah, Antologi Sastra Aceh Sekilas Sepintas. Jakarta: Yayasan Nusantara.

Hermansoemantri, Emuch. 1979. "Sajarah Sukapura, Sebuah Telaah Filologis”.

Disertasi Universitas Indonesia Jakarta.

Hurgronje, C. Snouck. 1906. The Achehnese, 2 Volumes. Leiden: Brill.

Iskandar, Mohammad. 2001. Para Pengemban Amanah, Pergulatan Pemikiran

Kiai dan Ulama di Jawa Barat, 1900-1950. Yogyakarta: Mata Bangsa.

Iskandarwassid, Ajip Rosidi, Josep CD. 1987. Naskah Karya Haji Hasan Mustapa, Bandung: Proyek Sundanologi.

Jahroni, Jajang. 1999. "The Life and Mystical Thought of Haji Hasan Mustafa (1852-1930)," Thesis, Leiden University.

Johns. A.H. 1965. The Gift Adressed to the Spirit of the Prophet, Canberra: Center of Oriental Studies A.N.U.

Kaptein, Nico. 1997. "Sayyid Uthman On the Legal Validity of Documentary Evidence," Bijdragen tot de Taal-, Land- en Volkenkunde 153, no: 1, Leiden.

Kartini, Tini, et.al. 1985. Biografi dan Karya Pujangga Haji Hasan Mustapa, Jakarta: Pusat Pembinaan dan Pengembangan Bahasa Depdikbud Jakarta.

Knysh, Alexander. 1995. "Ibrāhīm al-Kūrānī (d. 1101/1690), an Apologist for "wahdat al-wujūd," Journal of the Royal Asiatic Society, Third Series, Vol. 5, No. 1, Apr.

Laffan, Michael Francis. 2003. Islamic Nationhood and Colonial Indonesia, The Umma below the Winds. London-New York: Routledge Curzon. . 2011. The Makings of Indonesian Islam, Orientalism and the Narration of a Sufi Past, Princeton: Princeton University Press.

Lubis, Nina H. 1998. Kehidupan Menak Priangan 1800-1942. Bandung: Pusat Informasi Kebudayaan Sunda.

Mas'ud, Abdurrahman Mas'ud. 2004. Intelektual Pesantren: Perhelatan Agama dan Tradisi. Yogyakarta: LKiS. 
Millie, Julian. 2014. “Arriving at the Point of Departing, Recent Additions to the Hasan Mustapa Legacy," Bijdragen tot de Taal-, Land-en Volkenkunde, 170.

Moriyama, Mikihiro. 2005. Semangat Baru: Kolonialisme, Budaya Cetak dan

Kesastraan Sunda Abad ke-19, trans. Suryadi. Jakarta: KPG.

Mustapa, Haji Hasan. 1913. Bab Adat ${ }^{2}$ Oerang Priangan Djeung Oerang Soenda

Lian ti Eta, Ditjitakna di kantor tjitak Kangdjeng Goepernemen di nagara Batawi.

. Dangding Djilid Anu Kaopat, stensilan kenging ngusahakeun Ajip Rosidi, Tjihideung, Oktober 1960.

. 1976. Gendingan Dangding Sunda Birahi Katut Wirahmana Djilid

A. Bandung: Jajasan Kudjang.

. 2009. Seri Guguritan Haji Hasan Mustapa (Asmarandana Nu Kami,

Kinanti Kulu-kulu, Sinom Wawarian, Dangdanggula Sirna Rasa, Sinom

Barangtaning Rasa). Bandung: Kiblat.

Ricklefs, M. C. 2013. Mengislamkan Jawa, terj. FX. Dono Sunardi dan Satrio Wahono. Jakarta: Serambi.

Riddell, Peter G. 2001. Islam and the Malay-Indonesian World: Transmission and Responses. London: University of Hawaii Press.

Rohmana, Jajang A. 2012. 'Sundanese Sufi Literature and Local Islamic Identity: A Contribution of Haji Hasan Mustapa's Dangding.' Journal AlJamiah, Vol. 50, No. 2.

. 2013. "Makhtutat Kinanti [Tutur teu Kacatur Batur]: Tasawwuf al-‘Ālam al-Sūndāwī 'ind al-Ḥajj Ḥasan Mustafā (1852-1930)," Studia Islamika, Vol. 20, No. 2.

Rosidi, Ajip. 1983. Ngalanglang Kasusastran Sunda, Jakarta: Pustaka Jaya. . 1989. Haji Hasan Mustapa jeung Karya-karyana. Bandung: Pustaka.

ed. 2003. Ensiklopedi Sunda, Alam, Budaya, dan Manusia. Jakarta: Pustaka Jaya.

2009. Manusia Sunda. Bandung: Kiblat.

. 2010. Mencari Sosok Manusia Sunda. Bandung: Pustaka Jaya.

Rusyana, Yus. dan Ami Raksanegara. 1980. Puisi Guguritan Sunda. Jakarta:

Pusat Pembinaan dan Pengembangan Bahasa Depdikbud.

Schimmel, Annemarie. 1971. Mystical Dimentions of Islam. Chapel Hill: The University of North Carolina Press. 
. 1982. As Through a Veil: Mystical Poetry in Islam, New York:

Columbia University Press.

. 1993. The Triumphal Sun: A Study of the Works of Jalāluddin Rumi, New York: State University of New York Press.

Selim, Samah. 1990. "Mansur al-Hallaj and the Poetry of Ecstasy," Journal of Arabic Literature, 21: 1.

Setiawan, Hawe. 2012. "Dangding Mistis Haji Hasan Mustapa," Makalah Seri

Kuliah Umum Islam dan Mistisime Nusantara di Teater Salihara, 4 Agustus 2012.

Shah, Idries. 1977. The Sufis. London: The Octagon Press.

Shoheh, Muhamad. 2013. "Cerita Perbantahan Dahulu Kala: Pembelaan dan Sanggahan Tuanku Nan Garang atas Kritik Sayyid 'Utsmān bin Yahya bin 'Aqil Tahun 1885," Jumantara, Vol. 4 No. 1.

Simuh. 1988. Mistik Islam Kejawen Raden Ngabehi Ranggawarsita. Jakarta: UI-Press.

Smith, Margaret. 1932. The Persian Mystic Attar. New York: E. P. Dutton and Company Inc.

Soebardi, S. 1971. "Santri-Religious Elements as Reflected in the Book of Centini," Bijdragen tot de Taal-, Land-en Volkenkunde 127, No: 3, Leiden.

Martinus Nijhoof.

Solomon, Wendy. 1986. "Text and Personality: Ajip Rosidi in Search of Haji Hasan Mustapa," Indonesia Circle. School of Oriental \& African Studies. Newsletter, 14:41.

Steenbrink, Karel. 1995. "Qur'an Interpretations of Hamzah Fansuri (CA. 1600) and Hamka (1908-1982): A Comparison," Studia Islamika, Vol. 2, No. 2.

Trimingham, J. Spencer. 1977. The Sufi Orders in Islam, Oxford: Clarendon Press.

Vakily, Abdollah. 1997. "Sufism, Power Politics, and Reform: al-Raniri's Opposition to Hamzah al-Fansuri's Teaching Reconsidered," Studia Islamika, Vol. 4, No. 1: 113-135.

Van Ronkel, PH. S. 1942. "Aanteekeningen over Islam en Folklore in West-en Midden Java." BKI. 101: 311-339.

Wessing, Robert. 1974. "Cosmology and Social Behavior in A West Javanese Settlement." Diss. the University of Illinois at Urbana-Champaign. 